\title{
Immunocytochemical Study of the Endocrine Pancreas in the Rat during Normal Pregnancy and during Experimental Diabetic Pregnancy
}

\author{
F. A. Van Assche ${ }^{1}$, W. Gepts ${ }^{2}$, and L. Aerts ${ }^{1}$ \\ ${ }^{1}$ Unit for the Study of Reproduction, Department of Developmental Biology, K.U.L., Leuven, and ${ }^{2}$ Department of Pathology, V.U.B., \\ Brussel, Belgium
}

Summary. The distribution of different celltypes (A, $\mathrm{B}, \mathrm{D}$ and PP cells) of the endocrine pancreas was studied in both the normal and in the experimental diabetic non-pregnant and pregnant rat. In the normal rat the head (juxta duodenal part) of the pancreas contained more PP cells than the tail (12.5 \pm 1.1 versus $5.2 \pm 2.2$ ) but fewer glucagon cells (19.0 \pm 3.5 versus $14.3 \pm 3.6$ ). This difference disappeared during pregnancy, when the total $B$ cell mass increased (2.05 versus 0.82 ). In the diabetic rat no difference was found in the number of endocrine cells between the tail and the juxta duodenal part of the pancreas. Unlike the non-diabetic rat, the number of $B$ cells did not increase in the pancreas of the pregnant diabetic rat. An absolute increase in the number of glucagon (A) cells was demonstrated in the islets of the pregnant diabetic rat as compared to the non-diabetic rat (35 versus 21.2).

Key words: Pregnancy, experimental diabetes, islets of Langerhans, immunocytochemical techniques, insulin, glucagon, pancreatic polypeptide, somatostatin.

An increased bulk of endocrine tissue, an increased amount of B cells and increased B cell granulation have been demonstrated in normal pregnancy in the rat $[1,20]$.

These morphological findings may be correlated with the hyperinsulinism noted in animal and human pregnancy $[3,6,8,12,15,17,18]$.

However, no morphological study of the endocrine pancreas in pregnancy has been performed using immunocytochemical techniques; only a few authors have investigated whether the ability of the endocrine pancreas to adapt itself to the increased insulin requirements during pregnancy is preserved in animals with experimental diabetes [1].

The aim of the present paper was to study the relative proportions and distribution of $\mathrm{A}, \mathrm{B}, \mathrm{D}$ and $\mathrm{PP}$ cells during pregnancy in the normal and streptozotocin diabetic rat pancreas.

\section{Material and Methods}

Twenty virgin female Wistar rats of comparable age ( \pm 80 days) and weight ( \pm 170 gram) were used for the experiments. Group I (the controls) comprised 10 rats, 5 of which became pregnant and 5 remained non-pregnant. Group II comprised 10 rats which were each injected with $50 \mathrm{mg}$ streptozotocin $/ \mathrm{kg}$ body weight; five of these rats were mated on the day of the injection. All the rats were caged at room temperature and received food and water ad libitum. The rats were killed and the pancreas from each was removed and weighed on day 20 of the experiment, day 1 being the same whether the animals were injected with streptozotocin, mated or both. The same starting day was assumed for the controls which were neither mated nor injected.

Mating was performed on the same day. Pregnancy was confirmed by the finding of a copulation plug. Only rats with litter size between 9 and 12 fetuses were retained for the study. Reference markers were attached at the head and the tail of the pancreas. The total pancreas was fixed in Bouin's solution and sections, $3 \mu \mathrm{m}$ thick, were cut from tissue embedded in paraffin wax. Guinea pig antiserum to bovine insulin was a generous gift of Dr. A. Lambert (Université de Louvain, Belgium). Rabbit antiserum to bovine pancreatic polypeptide was kindly provided by Dr. R. Chance (Eli Lilly, Inc. Indianapolis, Ind. U.S.A.). Rabbit antiserum to glucagon, somatostatin and the PAP-complex were prepared in our laboratory. The immunocytochemical stain of the islet cell hormones was accomplished by using the unlabelled antibody enzyme method of Sternberger et al. [19]. The dilution of the antisera was: $1 / 20000$ for anti-insulin and for anti-somatostatin, $1 / 10000$ for anti-glucagon, $1 / 40000$ for anti-pancreatic polypeptide. The PAPcomplex was used at a dilution of $1 / 300$.

Controls for antisera specificity were performed by substituting normal serum for a specific antiserum or by absorbing specific antiserum with an excess of the related antigen. 
Table 1. Features of the endocrine pancreas in non-pregnant and pregnant rats (Mean $\pm S D$ )

\begin{tabular}{|c|c|c|c|c|c|c|c|}
\hline & & \multirow{2}{*}{$\begin{array}{l}\text { Non-fasting } \\
\text { blood glucose } \\
\mathrm{mg} / 100 \mathrm{ml}\end{array}$} & \multicolumn{2}{|c|}{ Weight animals (g) } & \multirow{2}{*}{$\begin{array}{l}\text { Weight } \\
\text { pancreas } \\
\text { (mg) }\end{array}$} & \multirow{2}{*}{$\begin{array}{l}\text { Endocrine } \\
\text { tissue } \\
(\%)\end{array}$} & \multirow{2}{*}{$\begin{array}{l}\text { Total number } \\
\text { of cells } \\
\text { per islet }\end{array}$} \\
\hline & & & $\begin{array}{l}\text { before the } \\
\text { experiment }\end{array}$ & $\begin{array}{l}\text { day } 20 \text { of the } \\
\text { experiment }\end{array}$ & & & \\
\hline \multicolumn{8}{|l|}{ Group I } \\
\hline \multirow[t]{2}{*}{ Controls } & $\begin{array}{l}\text { a) Non-pregnant } \\
\text { b) Pregnant }\end{array}$ & $\begin{array}{l}96 \pm 7 \\
85 \pm 10\end{array}$ & $\begin{array}{l}162 \pm 8 \\
165 \pm 7\end{array}$ & $\begin{array}{l}166 \pm 10 \\
201 \pm 31\end{array}$ & $\begin{array}{l}411 \pm 37.3 \\
432 \pm 43.2\end{array}$ & $\begin{array}{l}0.9 \pm 0.3 \\
2.2 \pm 0.5\end{array}$ & $\begin{array}{r}71 \pm 18 \\
122 \pm 42\end{array}$ \\
\hline & $\mathrm{P}$ & NS & NS & 0.005 & NS & 0.001 & 0.001 \\
\hline \multicolumn{8}{|l|}{ Group II } \\
\hline $\begin{array}{l}50 \mathrm{mg} \\
\text { streptozotocin }\end{array}$ & $\begin{array}{l}\text { a) Non-pregnant } \\
\text { b) Pregnant } \\
\mathbf{P}\end{array}$ & $\begin{array}{l}389 \pm 27 \\
365 \pm 93 \\
\text { NS }\end{array}$ & $\begin{array}{l}170 \pm 7 \\
168 \pm 6 \\
\text { NS }\end{array}$ & $\begin{array}{l}167 \pm 6 \\
165 \pm 8 \\
\text { NS }\end{array}$ & $\begin{array}{l}417 \pm 33.3 \\
420 \pm 12.6 \\
\text { NS }\end{array}$ & $\begin{array}{l}0.5 \pm 0.1 \\
0.5 \pm 0.06 \\
\text { NS }\end{array}$ & $\begin{array}{l}49 \pm 17 \\
65 \pm 21 \\
\text { NS }\end{array}$ \\
\hline
\end{tabular}

Table 2. Different cell-types in the non-pregnant and pregnant controls (Mean $\pm \mathrm{SD}$ )

\begin{tabular}{llcl}
\hline Hormone & & $\begin{array}{l}\text { Non-pregnant } \\
\% / \text { total } \\
\text { islet cells }\end{array}$ & $\begin{array}{l}\text { Pregnant } \\
\% / \text { total } \\
\text { islet cells }\end{array}$ \\
\hline $\begin{array}{l}\text { Somatostatin } \\
\text { (D cells) }\end{array}$ & tail & $12.9 \pm 1.3$ & $6.6 \pm 2.1$ \\
Pancreatic & head & $9.6 \pm 2.4$ & $5.8 \pm 2.8$ \\
$\begin{array}{l}\text { polypeptide } \\
\text { (PP cells) }\end{array}$ & head & $5.2 \pm 2.2$ & $8.0 \pm 3.3$ \\
$\begin{array}{l}\text { Glucagon } \\
\text { (A cells) }\end{array}$ & tail & $12.5 \pm 1.1$ & $8.2 \pm 2.9$ \\
Insulin & head & $14.3 \pm 3.6$ & $17.4 \pm 2.0$ \\
(B cells) & tail & $60.6 \pm 7.2$ & $66.8 \pm 3.5$ \\
\hline
\end{tabular}

Counting of the different celltypes was performed in the islets of the juxta duodenal (head) and the caudal (tail) parts of the pancreas. At least 200 islets were counted per animal in each region. The juxta duodenal part of the pancreas was defined as the part which is confined within the duodenal curvature. Three to four sections, 15 to $18 \mu \mathrm{m}$ apart, were used. The nucleus was taken as counting base. Slides were also stained with Ivic victoria blue, acid fuchsin method [10] for the demonstration of endocrine and exocrine tissue. The volume ratio of endocrine to exocrine tissue plus connective tissue was calculated by the morphometric method of Chalkley [4]. The volume density for the different celltypes was calculated by multiplying the volume density of the endocrine tissue per total pancreas by the mean percentage of the different celltypes per total cells in the islets. This calculation estimates the percentage volume per total pancreas occupied by the different celltypes.

The calculation of the volume density was in initially performed on the assumption that all the endocrine cells are of equal size. Secondly, we corrected the volume density, since Hellman [7] has shown that the volume of the individual $\mathrm{B}$ cell in the normal rat is three times the volume of the A cell, using the formula $3 \mathrm{nx} 100$ / $2 n+100$, where $n$ is the percentage of $B$ cells per total islet cells.

The number of the different celltypes per islet section was calculated from the mean total number of cells per islet section and the percentage of the celltypes per total islet cells.

Glucose concentrations in the blood were determined on day $20(0900 \mathrm{~h})$ by the ferricyanide method [9] using the Technicon autoanalyser. On day 19 , urine was collected for the detection of glycosuria using clinitest, (Ames), proteinuria (BM test, Boehringer) and acetonuria (Acetest, Ames). The results were compared statistically by Student's t-test and differences were considered as significant if $\mathrm{p}<0.05$.

\section{Results}

\section{General Features}

Diabetic rats showed increased blood glucose levels. At day 19 of pregnancy acetonuria and proteinuria was found. No weight change occured in the nonpregnant rats. The weight of the animals increased during normal pregnancy, but not during diabetic pregnancy. The weight of the pancreas in the pregnant rats was not different from the weight of the pancreas in non-pregnant rats in both controls and in the diabetic animals. The amount of endocrine tissue and the total number of cells per islet increased during normal pregnancy, but not during diabetic pregnancy (Table 1).

\section{The Different Celltypes}

a) Normal Rats. The percentage of somatostatin cells decreased during pregnancy $(\mathrm{p}<0.01)$. The percentage of pancreatic polypeptide (PP) cells in the islets was higher in the head of the pancreas than in the tail $(\mathrm{p}<0.05)$. The percentage of glucagon cells was higher in the tail than in the head $(\mathrm{p}<0.05)$. This difference disappeared during pregnancy. The percentage of insulin producing $B$ cells in the islets was increased during pregnancy $(\mathrm{p}<0.01)$ (Table 2$)$.

The volume density of the somatostatin cells per total pancreas did not increase during pregnancy. The volume density of the PP cells increased fourfold during pregnancy. The volume density of the 
Table 3. Amount of different cells in non-pregnant and pregnant normal rats taken from the tail of the pancreas

\begin{tabular}{|c|c|c|c|c|c|c|c|c|}
\hline \multirow[b]{2}{*}{ Hormone } & \multicolumn{4}{|c|}{ Non-pregnant } & \multicolumn{4}{|l|}{ Pregnant } \\
\hline & $\begin{array}{l}\% / \text { total } \\
\text { islet cells }\end{array}$ & $\begin{array}{l}\text { Volume } \\
\text { density/ } \\
\text { total } \\
\text { pancreas }\end{array}$ & $\begin{array}{l}\text { Corrected } \\
\text { volume } \\
\text { density/ } \\
\text { total } \\
\text { pancreas }\end{array}$ & $\begin{array}{l}\text { Number of } \\
\text { cells/islet }\end{array}$ & $\begin{array}{l}\% / \text { total } \\
\text { islet cells }\end{array}$ & $\begin{array}{l}\text { Volume } \\
\text { density/ } \\
\text { total } \\
\text { pancreas }\end{array}$ & $\begin{array}{l}\text { Corrected } \\
\text { volume } \\
\text { density/ } \\
\text { total } \\
\text { pancreas }\end{array}$ & $\begin{array}{l}\text { Number of } \\
\text { cells/islet }\end{array}$ \\
\hline Somatostatin & 12.9 & 0.11 & 0.03 & 9.1 & 6.6 & 0.14 & 0.03 & 8.0 \\
\hline $\begin{array}{l}\text { Pancreatic } \\
\text { polypeptide }\end{array}$ & 5.2 & 0.04 & 0.01 & 3.6 & 8.0 & 0.17 & 0.04 & 9.7 \\
\hline Glucagon & 19.0 & 0.16 & 0.04 & 13.4 & 17.4 & 0.38 & 0.08 & 21.2 \\
\hline Insulin & 60.6 & 0.53 & 0.82 & 43.0 & 66.8 & 1.46 & 2.05 & 81.4 \\
\hline
\end{tabular}

Endocrine tissue (\%): non-pregnant $0.9 \pm 0.3$

$\begin{array}{lll} & \text { pregnant } & 2.2 \pm 0.5 \\ & & 71 \pm 18\end{array}$

pregnant $122 \pm 42$

Statistics were not performed on these results, since they were calculated from the mean of the results shown below on the table

Table 4. The different cell-types in the non-pregnant and pregnant diabetic rats (Mean $\pm \mathrm{SD}$ )

\begin{tabular}{llll}
\hline Hormone & Non-pregnant & $\begin{array}{l}\text { Pregnant } \\
\% / \text { total } \\
\text { islet cells }\end{array}$ & $\begin{array}{l}\text { \%/total } \\
\text { islet cells }\end{array}$ \\
\hline $\begin{array}{l}\text { Somatostatin } \\
\text { (D cells) }\end{array}$ & tail & $18.2 \pm 7.2$ & $15.9 \pm 1.9$ \\
Pancreatic & tail & $15.7 \pm 5.1$ & $16.6 \pm 2.6$ \\
polypeptide & head & $15.3 \pm 4.9$ & $15.5 \pm 2.4$ \\
(PP cells) & tail & $53.5 \pm 6.8$ & $53.9 \pm 11.6$ \\
Glucagon & head & $46.5 \pm 12.8$ & $48.8 \pm 13.4$ \\
(A cells) & tail & $12.3 \pm 1.8$ & $12.6 \pm 1.9$ \\
Insulin & head & $19.1 \pm 2.1$ & $15.3 \pm 2.8$ \\
(B cells) & & & \\
\hline
\end{tabular}

glucagon cells increased two-fold and the volume density of the insulin cells increased nearly threefold. The mean number of insulin cells per islet was only doubled (Table 3).

b) Diabetic Rats. The islets in the head and in the tail of the pancreas had the same cytological composition, except that in the non-pregnant rats the B cells were more numerous in the islets of the head. The percentage of the 4 different celltypes was not different in the non-pregnant rats (Table 4).

Neither the volume density per total pancreas of the 4 hormone containing cells, nor the number of cells per islet changed during diabetic pregnancy, whereas in normal pregnancy the volume density of the B cells increased three-fold (Table 5).

\section{Comparison of the Pancreas of the Normal and Diabetic Pregnant Rat}

Comparing the non-diabetic pregnant rats with the diabetic pregnant rats it is clear that the percentage of insulin cells was significantly $(\mathrm{p}<0.001)$ decreased in the diabetic state. The percentage of the other celltypes was increased. The most pronounced increase was in glucagon cells $(\mathrm{p}<0.001)$ (Fig. 1 , Table 2, 4).

The mean number of $\mathrm{B}$ cells per islet decreased, whereas the mean number of A cells per islet increased (Fig. 1, Table 3, 5).

\section{Discussion}

Our study has confirmed that the normal endocrine pancreas is able to adapt to the metabolic changes of pregnancy by islet hypertrophy. The enlargement of islet volume is mainly due to an increased number of $B$ cells, but also to an hypertrophy of the individual B cell. Indeed the volume density of the B cells per total pancreas was nearly trebled, whereas the mean number of B cells per islet was only doubled. The percentage endocrine tissue in the diabetic rat was about half that in the non-pregnant normal rat, whereas the total number of cells per islet was similar. This can be explained by the fact that the volume of the $\mathrm{B}$ cells is greater than that of the other islet cells.

Orci et al. [14] have reported an irregular distribution of the PP cells and glucagon cells, the proportion of PP cells being higher in the islets of the 
Table 5. Amount of different cells in non-pregnant and pregnant diabetic rats taken from the tail of pancreas

\begin{tabular}{|c|c|c|c|c|c|c|c|c|}
\hline \multirow[b]{2}{*}{ Hormone } & \multicolumn{4}{|c|}{ Non-pregnant } & \multicolumn{4}{|l|}{ Pregnant } \\
\hline & $\begin{array}{l}\% / \text { total } \\
\text { islet cells }\end{array}$ & $\begin{array}{l}\text { Volume } \\
\text { density/ } \\
\text { total } \\
\text { pancreas }\end{array}$ & $\begin{array}{l}\text { Corrected } \\
\text { volume } \\
\text { density/ } \\
\text { total } \\
\text { pancreas }\end{array}$ & $\begin{array}{l}\text { Number of } \\
\text { cells/islet }\end{array}$ & $\begin{array}{l}\% / \text { total } \\
\text { islet cells }\end{array}$ & $\begin{array}{l}\text { Volume } \\
\text { density } \\
\text { total } \\
\text { pancreas }\end{array}$ & $\begin{array}{l}\text { Corrected } \\
\text { volume } \\
\text { density/ } \\
\text { total } \\
\text { pancreas }\end{array}$ & $\begin{array}{l}\text { Number of } \\
\text { cells/islet }\end{array}$ \\
\hline Somatostatin & 18.2 & 0.09 & 0.07 & 8.9 & 15.9 & 0.08 & 0.07 & 10.3 \\
\hline $\begin{array}{l}\text { Pancreatic } \\
\text { polypeptide }\end{array}$ & 15.3 & 0.07 & 0.06 & 7.4 & 15.5 & 0.07 & 0.07 & 10.0 \\
\hline Glucagon & 53.5 & 0.27 & 0.21 & 26.2 & 53.9 & 0.25 & 0.23 & 35.0 \\
\hline Insulin & 12.3 & 0.06 & 0.16 & 6.3 & 12.6 & 0.05 & 0.13 & 8.1 \\
\hline
\end{tabular}

Endocrine tissue (\%):

non-pregnant $0.5 \pm 0.1$

Number of total cells per islet section: non-pregnant $49 \pm 17$

pregnant $65 \pm 21$

Standard deviation and t-test were not performed on these results, since they were calculated from the mean of the results shown below on the table
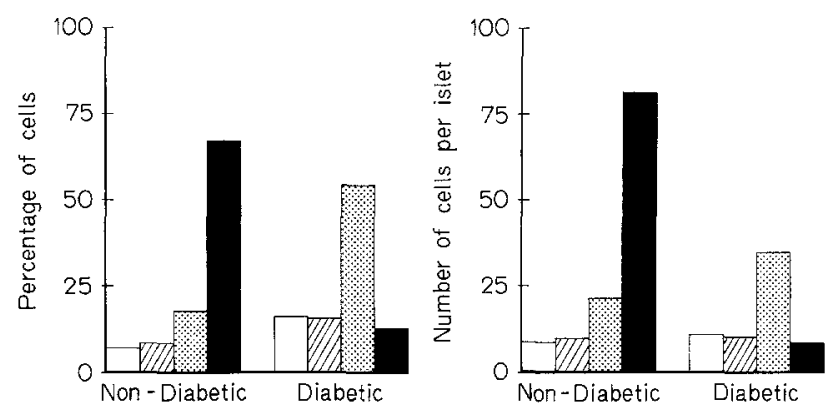

Fig. 1. Comparison between non-diabetic and diabetic pregnant rats (tail of the pancreas) $\square$ Somatostatin - P.P. - Glucagon Insulin

head than in the islets of the tail and the proportion of glucagon cells being higher in the islets of the tail than in the islets of the head. Our study confirms these data, but reveals also that the differences tend to disappear during pregnancy.

It is therefore important to mention that sampling in different areas of the pancreas is necessary in a morphometric study. The anabolic condition of pregnancy could be enhanced by the high ratio of the volume density between insulin and glucagon cells [13].

The fact that the islet tissue and the insulin cells fail to develop during diabetic pregnancy confirms that the endocrine pancreas of pregnant rats with experimental diabetes is no longer able to meet the increased insulin requirements of pregnancy. This observation could be explained in the light of the observation of Logothetepoulos [11] that the B cell has a limited capacity to replicate. On the other hand the $B$ cells require a normal metabolic environment to proliferate $[5,16]$. It is also possible that the residual $B$ cells have been damaged, but not destroyed, by streptozotocin and are consequently unable to replicate.

The lower percentage of insulin cells in the pregnant diabetic rats compared with the pregnant nondiabetic rats is not unexpected. The percentage of the other cell types increased. The increase is relative for the PP cells and for the somatostatin cells, whereas it is absolute for the glucagon cells. The decreased ratio of the volume density of insulin cells to glucagon cells fits with the catabolic conditions of severe ketotic diabetes and pregnancy. Indeed the fetuses of these pregnant rats show intrauterine growth retardation [2].

Acknowledgements. The technical assistance of L. VerhoevenVerhelst is acknowledged. This work was supported by Grant, $\mathrm{N}^{\circ}$ 20.334 from Fonds voor Geneeskundig Wetenschappelijk onderzoek.

\section{References}

1. Aerts L, Van Assche FA (1977) Ultrastructural changes of the endocrine pancreas in pregnant rats. Diabetologia 11: 285-289

2. Aerts L, Van Assche FA (1977) Rat foetal endocrine pancreas in experimental diabetes. J Endocrinol 73: 339-346

3. Bone AG, Taylor KW (1976) Metabolic adaptation to pregnancy shown by increased biosynthesis of insulin in islets of Langerhans isolated from pregnant rats. Nature 262: 501-502

4. Chalkley HW (1943) Method for quantitative morphologic analysis of tissues. Int Cancer Inst 4: 47-53 
5. Eff C, Faber OK, Deckert T (1977) C-peptide secretion in long-term juvenile diabetics with and without complications. Diabetologia 13: 391

6. Green IC, Taylor KW (1974) Effects of pregnancy in the rat on the size and insulin secretory response of the islets of Langerhans. J Endocrinol 62: 137-143

7. Hellman B (1959) The effect of ageing on the total volumes of the A and B cells in the islets of Langerhans of the rat. Acta Endocrinol (Kbh) 32: 92-112

8. Heliman B (1960) The islets of Langerhans in rat during pregnancy and lactation with special reference to the B/A cell ratio. Acta Obstet Gynecol Scand 39: 317-323

9. Hoffman WS (1973) A rapid photoelectric method for the determination of glucose in blood and urine. J Biol Chem 120: $51-55$

10. Ivic M (1959) Neue selektive Farbungsmethode der A und B Zellen der Langerhans. Inseln. Anat Anz 107: 347-350

11. Logothetopoulos J (1972) Islet cell regeneration and neogenesis. In: Steiner DF, Freinkel $\mathrm{H}$ (eds) Handbook of physiology, endocrinology, endocrine pancreas. Williams and Wilkins, Baltimore, p 67-76

12. Malaisse WJ, Malaisse-Lagae F, Picard D, Flament-Durant J (1969) Effects of pregnancy and chorionic growth hormone upon insulin secretion. Endocrinology 84: 41-44

13. Nitzan M, Freinkel N, Metzger BE, Faloona GR, Daniel RR (1975) Interrelations of glucose, insulin and glucagon after overnight fast and in response to oral glucose during late pregnancy. Isr J Med Sci 11: 617-622

14. Orci L, Baetens D, Ravazzota R (1976) Ilots à polypeptide pancréatique (PP) et îlots à glucagon: distribution topographi- que distincte dans le pancréas du rat. C R Acad Sci [D] (Paris) 283: $1213-1216$

15. Rishi S, Golob EK, Becker KL, Shah N (1969) Pancreatic insulin content of non-pregnant, pregnant and postpartum rats and the developing rat fetus. Diabetes 18: 268-272

16. Shuji I, Bray GA (1977) Effect of transplantation of pancreas and development of hypothalamic obesity. Nature 266: 743-744

17. Spellacy WN (1971) Plasma insulin, growth hormone and placental lactogen levels in normal and abnormal pregnancies. Acta Endocrinol (Kbh) 155: 82

18. Spellacy WN, Goetz FC (1963) Plasma insulin in normal and late pregnancy. N Engl J Med 268: 988-991

19. Sternberger LA, Handy PH, Cuculis JJ, Meyer HC (1976) An unlabeled antibody method of immunochemistry. J Histochem Cytochem 18: 315-340

20. Van Assche FA (1974) Quantitative morphologic and histoenzymatic study of the endocrine pancreas in non-pregnant and pregnant rats. Am J Obstet Gynecol 118: 39-41

Received: August 10, 1979,

and in revised form: December 17, 1979

Prof. Dr. F. A. Van Assche

Department of Obstetrics and Gynaecology

K.U.L., Acad. Ziekenhuis St. Rafaël

Capucienenvoer, 35

B-3000 Leuven

Belgium 